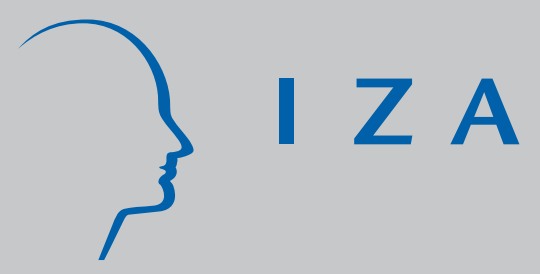

IZA DP No. 3445

Paintings and Numbers:

An Econometric Investigation of Sales Rates,

Prices and Returns in Latin American Art Auctions

Nauro F. Campos

Renata Leite Barbosa

April 2008 


\title{
Paintings and Numbers: An Econometric Investigation of Sales Rates, Prices and Returns in Latin American Art Auctions
}

\author{
Nauro F. Campos \\ Brunel University, \\ CEPR, WDI and IZA
}

\section{Renata Leite Barbosa}

Biscoito Fino Inc.

\author{
Discussion Paper No. 3445 \\ April 2008
}

\author{
IZA \\ P.O. Box 7240 \\ 53072 Bonn \\ Germany \\ Phone: +49-228-3894-0 \\ Fax: +49-228-3894-180 \\ E-mail: iza@iza.org
}

\begin{abstract}
Any opinions expressed here are those of the author(s) and not those of IZA. Research published in this series may include views on policy, but the institute itself takes no institutional policy positions.

The Institute for the Study of Labor (IZA) in Bonn is a local and virtual international research center and a place of communication between science, politics and business. IZA is an independent nonprofit organization supported by Deutsche Post World Net. The center is associated with the University of Bonn and offers a stimulating research environment through its international network, workshops and conferences, data service, project support, research visits and doctoral program. IZA engages in (i) original and internationally competitive research in all fields of labor economics, (ii) development of policy concepts, and (iii) dissemination of research results and concepts to the interested public.
\end{abstract}

IZA Discussion Papers often represent preliminary work and are circulated to encourage discussion. Citation of such a paper should account for its provisional character. A revised version may be available directly from the author. 


\section{ABSTRACT \\ Paintings and Numbers: An Econometric Investigation of Sales Rates, Prices and Returns in Latin American Art Auctions*}

This paper uses a unique data set of Latin American paintings auctioned by Sotheby's between 1995 and 2002 to investigate several puzzles from the recent auctions literature. Our results suggest that: (1) the reputation of an artist and the provenance of the artwork, omitted variables in most previous studies, seem to be more important determinants of the sale price of a painting than standard factors, such as medium and size, (2) the opinion of art experts seems to be of limited use in predicting whether or not an artwork sells at auction, (3) there is little supporting evidence for the widespread notion that the best or more expensive artworks tend to generate above average returns (the "masterpiece effect"), although (4) there is strong evidence in our data for the declining price anomaly, or "afternoon effect."

JEL Classification: D44, G11, L12, Z10

Keywords: art auctions, masterpiece effect, declining price anomaly, Latin American art

Corresponding author:

Nauro F. Campos

Department of Economics

Brunel University

West London, UB8 3PH

United Kingdom

E-mail: nauro.campos@brunel.ac.uk

\footnotetext{
* We would like to thank two anonymous referees and seminar participants at the 2004 Applied Econometrics Association Conference on the "Econometrics of Cultural Goods" (Padua) for valuable comments on a previous version of this paper. All remaining errors are our own.
} 


\section{Introduction}

In the last two decades or so, there has been a dramatic increase in economists' interest in auctions. ${ }^{1}$ Although the bulk of this literature is still theoretical, the attendant econometric evidence, in which the analysis of art auctions figure prominently, ${ }^{2}$ is catching up rapidly.

A common point of departure in recent studies is a Lancastrian interpretation where the various attributes or characteristics of an artwork — such as subject matter, medium and size - are considered to be key factors in explaining consumer's valuation. A large number of private firms monitor art auctions and commercialize information on such attributes. ${ }^{3}$ However, these electronic data sets contain only a fraction of the pre-auction information made available by the auction houses. They contain much less information, for example, than pre-auction catalogues. If one believes that auction houses are selective in the information they provide to potential buyers, then the exclusion of a share of this information in electronic databases is difficult to justify and its omission in econometric analyses should generate important biases in the case that relevant variables are omitted. ${ }^{4}$

For this paper, in which we study four important puzzles from the empirical literature on auctions, we have constructed a rich, unique data set, collecting by hand all the information presented in auction catalogues. This more comprehensive approach enables us to consider the effects of various potentially important variables that have received less attention in the literature thus far. We believe that this is not because the data were unimportant or unavailable, but maybe because the private firms that specialize in the provision of electronic

\footnotetext{
${ }^{1}$ See, e.g., Klemperer (2004) for a comprehensive review of this literature.

${ }^{2}$ See, e.g., Throsby (1994).

${ }^{3}$ Some of the main international fine art data providers are Art Price Index (http://web.artprice.com/), Art Sales Index (www.art-sales-index.com), Guide Mayer (http://www.guidemayer.com/) and Gabrius (http://www.gabrius.com/).

${ }^{4}$ Quite a few researchers have taken the position that the dominant strategy is for galleries and auction houses to provide accurate and complete information (e.g. Ashenfelter, 1989). The point here is that most of the existing econometric research uses commercial electronic databases. These databases are selective in that they do not contain all the information available (for instance, in pre-auction catalogues) and focus on a relatively small number of variables.
} 
data on art auctions judged that information, say on artist's reputation and the provenance of artwork, would be common knowledge to art auction players or because, as it will be seen below, quantifying this type of information can be particularly expensive and timeconsuming. However, this should imply neither that this information in unobservable to the analyst nor that it is irrelevant to art buyers. Sotheby's and other auction houses sell these catalogues as well as subscriptions to catalogue series. They are luxurious publications of approximately 200 pages per auction. They contain data about each lot and about each individual artist. They present information on the artist's date of birth and of death, if applicable, nationality, dimensions of the work, a high-quality colour photographic reproduction of the work, medium, date of execution, provenance, as well as a low- and a high-price pre-sale estimate for the work (produced by Sotheby’s in-house art experts.)

For this paper, we coded by hand the catalogues of Sotheby's Latin American Art November auctions between 1995 and 2002. The ensuing data set includes approximately 1,640 paintings. We use this novel data set to study four puzzles. Firstly, the available econometric evidence from art auctions, which is based mostly on more established groups of painters such as Old Masters or Impressionists, suggests that factors such as medium and size are the main determinants of the price of artwork (e.g., Burton and Jacobsen, 1999): would these factors still play such a robust role when factors not normally considered in this literature (such as the provenance of the artwork, participation in major exhibitions and inclusion in the art literature) are taken into account? Note that the estimation of financial returns to art, which is one first step in addressing the three remaining puzzles, depends upon the quantification of the various characteristics of each painting and thus omitted variables bias can be severe and have widespread implications. ${ }^{5}$ Secondly, many art auctions analysts

\footnotetext{
5 This is true if the hedonic regression technique is being used, but it is not true if the repeat sales approach is taken to the analysis of financial returns to art. The repeat sales approach assesses the change in prices from repeated sales of the same painting over time. See below for further discussion.
} 
believe in the existence of a "masterpiece effect," namely, that the most expensive pieces of each artist command above normal returns. In a seminal paper, Pesando (1993) uses data on prints auctions to put forward evidence suggesting otherwise, that is, that masterpieces actually tend to under-perform the market. It would thus be interesting to investigate whether the effect also fail to obtain for our data. Thirdly, a common feature of art auctions is that not all lots are sold. “Bought-in” lots, using auction houses’ terminology, fail to command a price above the reserve set jointly by the seller. Recent research, based on more established groups of painters such as Impressionists, has uncovered an important role for art experts in this process. ${ }^{6}$ It would thus be valuable to investigate whether experts play a similar role in this segment of the market. Fourthly and finally, one resilient puzzle identified in the literature is the "declining price anomaly," or "afternoon effect," which refers to a decline in prices as the auction proceeds (Ashenfelter and Graddy, 2003; Ginsburgh and van Ours, 2003): would this anomaly also be observed for this largely untapped body of evidence?

Our main findings are as follows. First, we estimate and compare actual average prices, art expert's price estimates and hedonic prices. In doing so, we find that artist's reputation and the work's provenance turn out to be significantly more important price determinants than more commonly studied factors such as size, theme and medium. ${ }^{7}$ Second, and contrary to previous research (Ekelund et al., 1998; Mei and Moses, 2005), we find that experts' opinion is of rather limited power in predicting the sale of artwork. Third, and in line with previous research (Ashenfelter et al., 2002, Mei and Moses, 2002), we find that the “masterpiece effect” does not hold for our Latin American art data. Fourth, and also in line with previous research (Beggs and Graddy, 1997), we provide strong evidence that the

\footnotetext{
${ }^{6}$ The literature on the role of art experts often identifies these as those employed by the relevant internal departments of the auction houses. In this case, art experts would be those at the Latin American Art Department of Sotheby's.

${ }^{7}$ We also investigate the relation between price and artist's age, but did not find evidence of the nonlinear relationship established by Galeson (1999) for Modern masters.
} 
“declining price anomaly” holds for this data.

The rest of the paper is organised as follows. Section 2 reviews the related literature. Section 3 discusses methodological issues, while Section 4 details which and how information was hand-collected from the catalogues from Sotheby's Latin American Art November auctions from 1995 to 2002. Section 5 presents our main econometric results. Section 6 concludes.

\section{The Art Market: Workings and Evidence}

Art objects in general, and paintings in particular, are characterised by a set of attributes that distinguish them from other goods. Each unit of output is differentiated, an extreme case of a heterogeneous commodity. For the work of artists no longer living, supply is in a sense nonaugmentable. Because art works can be and are often resold, and their prices may rise over time, they have some characteristics of financial assets, and as such may be sought as a hedge against inflation, as a store of wealth or as a source of speculative capital gain. A Lancastrian interpretation is usually appropriate, where characteristics of works such as subject matter, colour palette, style, size and other aesthetic values enter the utility function for art as decoration; and expected rates of return, risk and other financial variables influence demand for art as an investment.

The art market is hierarchical and can be characterised as a series of closely linked markets. At the lowest level, sometimes referred to as the "primary" market, unorganised individual artists supply works to galleries, local art fairs, collective exhibitions, small dealers, and private buyers. At the "secondary" level, in markets located mostly in major cities where art is traded, such as New York, London, Paris, and Tokyo, established artists, dealers, and public and private collectors circulate works by artists who have managed to make the transition from the primary market. Finally, at the highest level, an international 
market exists in which the major auction houses are the main players, notably Sotheby's and Christie's, and where the works of artists of the highest reputation are traded at prices that often make headline news. Artists' careers can be thought of as a series of stages related to the stratified market structure, whereby advancement can be seen as stepping up from one market level to the next. Investors try to pick those artists who are most likely to make a transition to a higher stage, in the expectation that their prices may rise accordingly. Gerard-Varet (1995) interprets this transition from local to international markets in terms of reputation building: while at the primary or local markets, a limited number of buyers and less liquidity obtains because of a high degree of uncertainty regarding artwork quality, at the other extreme, in international markets, reputation resolves the information problem and generates a much higher number of buyers, much more liquidity and less market volatility. ${ }^{8}$ This is a very important point for one of our main arguments in this paper: there are many variables (many related to artist's reputation) that have been commonly omitted in the related empirical literature and their omission may have generated biased results and certainly have produced a partial or incomplete understanding of the process of pricing artworks. Latin American artists auctioned at Sotheby's are those with the highest possible reputations. It is not unreasonable to expect that the variance of their reputations is minimal in this segment of the market. If this is correct, it stacks the cards against us finding an important role for reputation.

The mechanics of the auction system is a critical determinant of how consumer preferences are translated into the valuation of artistic work. In 1977, Sotheby’s auction house began conducting semi-annual auctions of Latin American art at its New York branch (actually, Sotheby's held the first Mexican Paintings sale in 1977 and held the first auction of Latin American Art in 1979.) The records of these English style outcry auctions and the

\footnotetext{
8 Rouget and Sagot-Duvauroux (1996) argue that art experts play a major role in dealing with the uncertainty regarding the quality of artwork.
} 
information contained in the catalogues published by Sotheby's comprises a great deal of statistical information on the Latin American art market.

The art experts in Sotheby's Latin American Art Department, in conjunction with sellers, estimate a price range (reported in the pre-auction catalogue) within which they expect each painting to sell. ${ }^{9}$ The sellers of individual items will set a reserve price, and if the bidding does not reach that level, the item goes unsold or is "bought-in," i.e. when the maximum price that a potential buyer is willing to pay is less than the minimum price that a seller is willing to accept. The auction house does not publish, and indeed is very secretive about, the sellers' reserve price. Note that New York law prevents the reserve price to be above the lower price estimate. Auction houses earnings derive primarily from commissions charged to both buyers and sellers.

The literature has focused on two questions: how do rates of return on investment in art compare with returns elsewhere? And, related, what are the determinants of the price of art works?

Evidence on comparable rates of return between art and other assets suggest greater variability in the return to holding paintings rather than financial assets. The contribution of Baumol (1986) opened the way to a great number of studies on the rate of return on paintings. He associates investing in art to a floating crap game. Baumol calculate a real annual rate of return of $0.5 \%$ on paintings compared to $2.5 \%$ on government bonds over the period 1650 1960. Frey and Pommerehne (1989) estimate a 1.5\% real annual rate of return on paintings and a 3\% on government bonds over the period 1635-1987. This and other studies confirm Baumol's finding that art may be dominated as an investment vehicle. The return from owning art does not only consist in expected price rises but also in the psychic return, i.e. art

9 The Sotheby's Latin American Art Department in New York employs eminent experts in Latin American Art and has offices in Miami, Paris, Madrid, Buenos Aires, Caracas, Mexico City, Monterrey, Rio de Janeiro, São Paulo and Santiago de Chile. 
is also a consumption good. Frey and Eichenberger (1995) seek to analyse the determinants of the psychic returns from art. They suggest rental fees and willingness to pay studies as a possible way to measure these returns. Goetzmann (1993) suggests there is a strong relationship between demand for art and aggregate financial wealth. He also finds a positive relation between art and the stock market: "While returns to art investment have exceeded inflation for long periods, and returns in the second half of the $20^{\text {th }}$ century have rivalled the stock market, they are no higher than would be justified by the extraordinary risks they represent” (1993, p. 1370). Chanel (1995) offers evidence suggesting that financial markets influence the art market, with a lag of about one year.

In order to generate an estimate of returns on investment in art, the first step is the construction of a price index. There are three main methods used for this purpose: indices based on repeated sales, indices based on average art object and indices based on the hedonic regression approach (see Ginsburgh et al., 2006). Frey and Pommerehne (1989) use auction data on both demand and supply factors for 100 international contemporary artists. They find that aesthetic judgment of experts is a main determinant of the prices of art works. The painters and sculptors with the highest prices are, on the whole, those with the highest artistic achievement. Apart from aesthetic (expert) evaluation of the work, the artist's nationality and place of residence, size, style and medium of the work of art, advertising activities of the gallery, per capita income and the rate of return on traditional investment portfolios, are found to be important determinants of the sale price. With these explanatory variables, Frey and Pommerehne manage to account for 61 percent of the variance in prices. ${ }^{10}$

Valsan (2002) investigates the relationship between the market value of a work of art and the nationality of the painter. He analyses a sample of modern and contemporary Canadian and American paintings using non-parametric tests and a hedonic regression model.

\footnotetext{
${ }^{10}$ Interestingly, this figure is close to the one supported by our estimates, as discussed below.
} 
His data consists of 887 paintings, auctioned between 1987 and 1996. The information used on the artworks auctioned includes the date of the auction, dimensions and medium, price, art house and place of auctioning. Valsan observes that Canadian artists have a predilection for landscapes (92\% of his sample are landscapes) while American artists excel in compositions (79\% are compositions). He finds a relationship between market value and aesthetic painting characteristics, such as subject matter. Other things equal, Valsan finds that compositions command a premium over paintings with other subject matters. He suggests that, on average, American art is significantly more expensive that Canadian art because Canadian artists have avoided modern-type compositions; as they have focused instead on the Northern landscape. Therefore their artistic nationalism is one main reason that precluded them from gaining the same market recognition as their American counterparts.

Rengers and Velthuis (2002) analyse the determinants of prices for contemporary art focusing on gallery (rather than auction) prices in the Netherlands. They model price as a function of the work of art (size, material), the artist (age, gender, place of residence, institutional recognition), and the gallery (location, institutional affiliation, age). Their methodology differs in that they take into account the hierarchy of the data, using what they call multilevel rather than ordinary regression analysis. This approach allows them to see how much of the observed price difference is related to characteristics of works of art, how much can be attributed to the artists, and which part is due to gallery characteristics. Their data set contains prices and characteristics of over 12,000 works of art, sold between 1992 and 1998. They point out that the demand for works of art of extreme sizes (both small and big) is likely to be lower because odd formats are difficult to display. In empirical terms, this may translate into a non-linear relation between price and size. Furthermore, older artists have had more time to establish a network among critics and enhance their reputation; therefore they attain higher prices for their output. In the hedonic price function they estimate, the number of 
works sold by an artist has a significant positive effect on prices. This is the so-called "Veblen" effect on the art market, which means that collectors use prices as an indicator of quality - that is, success on the market translates into higher prices and increases in sales simultaneously. Strong overall predictors of art prices are the size and material of the work, and the age and place of residence of the artist. ${ }^{11}$

The econometric literature on the Latin American art market is still very small. In one of the few papers dedicated to this market, Ekelund et al. (1998) investigate the role of art experts in the context of Latin American Art auctions that took place between 1977 and 1996. They report that both Sotheby’s and Christie’s overestimated art by 2.7 percent and find that the "estimate "window," which is the product of the in-house art experts, is negatively and significantly related to the likelihood of a "no sale" at auction (we discuss this result in detail below). ${ }^{12}$

Edwards (2004) is one of the few papers offering an econometric analysis of the Latin American art market. In this case, the focus is on artist's careers and returns to art as an investment. One main result, using hedonic price indexes for the Latin Art market from 19812000, is that the correlation between returns on Latin art and returns on the Morgan Stanley Capital International (MSCI) World portfolio is very low.

Edwards discusses whether there is anything distinctive about Latin American art that could differentiate these results from those for European or American art. He notes as one important difference, despite the fact that "the market for many of the most important Latin

\footnotetext{
${ }^{11}$ Rengers and Velthuis note that their model can "account for 27 percent of the variance in prices in our data" (2002, p. 23). The fact that this share is smaller than that accounted for by Frey and Pommerehne (1998), and by our paper, is partly due to differences in method and specification (the use of artist's fixed-effects) and partly due to the fact that Rengers and Velthuis do not limit themselves to paintings, as we do here, but include sculpture and ceramics works in their sample. This increases the amount of variance to be explained and makes direct comparisons difficult. It is also worth stressing that artist's fixed-effects proxy for a number of "unobservables," including reputation.

${ }^{12}$ Using the same data set for a smaller number of painters, Ekelund et al. (2000) examine the effect of the death of an artist in the prices their paintings command in auctions.
} 
American artists is also quite liquid, with a large number of works by many of the masters being sold each year, (...) museum activity in this area of collecting is still limited. Thus-in contrast with American artists or the impressionists, for example-the market is not subject to the bias introduced by big museums, which tend to buy and retire some of the best works from the market” (2004, p. 2.) Another potentially important difference comes from the huge diversity one finds under Latin Art, as this encompasses art produced over more than 20 countries and over more than three centuries.

Economic and political developments in various Latin American countries may affect parts of the market differently, according to nationality. Anecdotal evidence suggests that when Latin Art auctions started in the early 1980s, it was relatively straightforward to identify buyers according to nationality: Mexicans tended to buy only Mexican artists, Brazilians tended to buy only Brazilian artists, and so on and so forth. However, this has changed significantly as the majority of buyers now seem to be US- or Europe-based (auction houses fiercely protect the anonymity of buyers so it is difficult to document this change rigorously). A common perception in the arts trade is that political developments also seem to matter, with many anecdotes about the coincidence between an election year in a given country and a reduction of the share of painters from that country in that year's auctions (e.g., if it is an election year in Argentina, there would less Argentinean painters being auctioned). Notice however that we could not find support for this type of pattern in our data (although it may be because ours cover a relatively short period of time).

Edwards also observes that one common problem with electronic databases is that they do not always include potentially important characteristics "of the pieces sold such as their specific style or whether they have been included in major exhibitions or retrospectives" (2004, p. 12). The issues of artist reputation and of the artworks provenance fall under this category. Although previous literature has recognized the importance of reputation and 
provenance, ${ }^{13}$ efforts to identify objective indicia of reputation of artists have been minimal in the visual arts literature and a thorough examination of the auction house catalogues is a rich source of information that can be used to improve the specification of equations estimating the price of paintings in auction markets. One of the first important studies in this respect is de la Barre et al. (1994), which "to represent reputation (...) chose to work with dummy variables for artists (or nationalities)" (p.151). Another recent paper that focus on this issue is Schönfeld and Reinstaller (2007). Although their contribution is mostly theoretical, they present and discuss in detail empirical results previously available only to German-speaking scholars (by Beckert and Rössel, 2004). They capture a number of factors reflecting the reputation of an artist (length of artist's career, art shows, public perception, and whether the artist holds a professorship) as well as gallery reputation. "However, none of the estimated coefficients (besides the length of an artist's career) are statistically significant” (Schönfeld and Reinstaller, 2007, p. 152). In our results, discussed below, the variables we construct for provenance and reputation often have coefficients that carry the expected sign and are statistically significantly different from zero, even when dummy variables for artists and nationalities (which is another way previous literature dealt with reputation) are included in the regressions.

\section{Methodology}

The hedonic price methodology has its origin in agricultural economics. Frederick V. Waugh (1928) published his pioneering paper on quality factors influencing vegetable prices. Waugh regressed the price of asparagus in Boston on three different dimensions of quality: measures of colour, size of stalks, and uniformity of spears. His purpose was to determine consumer's relative valuations of these characteristics, which he regarded as useful information for

\footnotetext{
${ }^{13}$ See Sagot-Duvauroux (2003) and references therein.
} 
asparagus producers. Court (1939) studied the changes in automobile prices over time in relation to their performance characteristics. Gregory Chow (1967) used a similar approach to measure the impact of technological changes on computer prices. Chanel et al. (1994, 1996), Chanel (1995) and Gerard-Varet (1995) discuss the use of hedonic models to construct art price indexes. $^{14}$

Consider the following model:

$$
\log \left(P_{i}\right)=a_{0}+\sum b_{i} X_{i}+\sum c_{t} Y(t)+e_{i}
$$

where $\log \left(P_{i}\right)$ is the natural logarithm of (say a painting's) price, $X_{i}$ represents a series of characteristics of the painting, $Y(t)$ represents a series of dummy variables which equals one if the painting is sold at time (or auction) $\mathrm{t}$ and zero otherwise, and $e_{i}$ is a random error term. The second term on the right side of the equation captures the impact of painting characteristics on the selling price. The third term captures the so-called pure price effect, i.e. the change in prices over time after controlling for painting characteristics (Triplett, 2004).

The next step is to obtain data on prices of varieties of a differentiated commodity, units of which embody varying amounts of different attributes or qualities. A regression model is then used to estimate the hedonic price function, the gradients of which are the implicit prices of the attributes, which in turn are expected to reflect consumer's marginal rates of substitution among attributes. This model of consumer behaviour does not restrict each consumer to purchase one variety or one unit of a particular variety as in Lancaster attribute model, and it does permit substitution among varieties. One disadvantage of these models is the strong assumption that a set of variables in $\mathrm{X}$ captures much of the variability in the fixed components of price and that the intrinsic characteristics of the objects offered do not vary systematically over time. ${ }^{15}$ The latter is obviously not relevant in this case, but with

\footnotetext{
${ }^{14}$ Nerlove (1995) and Hulten (2003) survey this literature.

${ }^{15}$ Computers and automobiles are cases in point. See Tomat (2002) for an analysis of the latter.
} 
respect to the former we believe that by comprehensively approaching data collection we are able to minimize the risk of severe omitted variables bias.

\section{Data}

The data set consists of prices and characteristics of 1,663 paintings by Latin American artists, auctioned by Sotheby’s in New York between 1995 and 2002. ${ }^{16}$ Basic statistics on the pooled data are presented in the Appendix. Not all lots auctioned were included in the analysis because we restrict the study to paintings and excluded works by anonymous artists. $^{17}$

As noted, our goal was to code by hand the entire pre-auction catalogue. These catalogues contain not only extensive information about the $\operatorname{lot}^{18}$ (the art object), but also (at the end) biographical information on each artist. The pre-auction catalogues are the source of all our data, with the obvious exception of the final sale prices, which are made available online by Sotheby's after the auction. ${ }^{19}$ Prices are in U.S. dollars and include what is known as the "buyer's premium”. For those lots that are not "bought-in", the last price announced by the auctioneer is the so-called hammer price, or successful bid price. A buyer's premium is added to the hammer price and is payable by the purchaser as part of the total purchase price. $^{20}$ Sotheby’s buyer's premium until April 1, 2000 was 15\% if the hammer price was less than $\$ 50,000$ and $10 \%$ if more. It changed after that date to $20 \%$ of the hammer price up to

\footnotetext{
${ }^{16}$ Sotheby's is the main player in the international market for Latin American Art. Sotheby's has achieved eight of the 10 highest prices for Latin American art, including the auction record, Frida Kahlo's self-portrait, Roots sold for \$5,616,000 in 2006.

${ }^{17}$ Less than 1 percent of the works listed in the pre-auction catalogues are not paintings, and they usually are sculpture and ceramics works. Anonymous works tend to be older (XVIII and XIX centuries) and of a religious theme, and they represent a very small share of Latin American art auctioned by Sotheby's. For instance, only 4\% of the paintings were by anonymous painters in 2002.

${ }^{18}$ Lots in this type of auction comprise one piece of work (that is, one painting).

19 Available at http://www.sothebys.com/

${ }^{20}$ The auction houses also charge a fee for their services to the seller, but this is undisclosed and is not constant. It varies based on, for instance, the number of works a seller would like to place in auction and the number of times in the past the seller has used the services of the auction house.
} 
$\$ 15,000,15 \%$ for $\$ 15,001$ to $\$ 99,999$ and $10 \%$ for pieces selling for more than $\$ 100,000$. In 2002, this changed again to $19.5 \%$ for pieces selling for up to $\$ 100,000$ and $10 \%$ if above this value. $^{21}$

The pre-auction catalogue also contains a range of estimates for the expected price a work of art should fetch in auction. These estimates are produced by art experts in Sotheby's Latin American Art Department and are in the form of a minimum and a maximum price. Although the maximum expected price is of little consequence, many in the trade believe that the minimum expected price is systematically related to the seller's (undisclosed) reserve price. Ashenfelter and Graddy (2003) argue that the rule of thumb for art auctions seems to be that the reserve price is $80 \%$ of the minimum price estimated by the auction house. If the hammer price is below the reserve price, the sale does not occur and the auction house announces this fact. The practice is now common in all major auction houses after a New York State law was passed in the 1980s requiring full disclosure of no sales.

If the painting is unsold, the variable price equals zero. This allows the creation of a dummy variable, sold, which equals 1 if the painting is sold and 0 otherwise. From the 1,663 paintings auctioned in our data set, about $67 \%$ were sold and $33 \%$ were "bought in". Notice that this is in line with other estimates from the literature (see Ashenfelter and Graddy, 2003). The mean price was $\$ 42,743$ and the maximum price for a painting was $\$ 2,642,500 .^{22}$

The pre-auction catalogue also provides information on whether the paintings were previously auctioned by Sotheby's (note the catalogue does not provide information on whether the painting was auctioned by other auction houses ${ }^{23}$ ). For instance, Mexican artist Rufino Tamayo’s painting “The Return” was auctioned by Sotheby’s in 1999 and sold for

\footnotetext{
${ }^{21}$ The results presented below are not affected if instead of using the hammer price, as reported, we use the net price (that is, excluding the "buyer's premium") as described above.

${ }^{22}$ The painting "The Disasters of Mysticism" by Matta sold in 1999.

${ }^{23}$ This is a limitation of these data. It would be better to have information on whether the painting has been sold in auction before at all instead of whether it has been sold only by Sotheby's.
} 
$\$ 90,500$. It was re-auctioned (again by Sotheby’s) in 2001 and sold for $\$ 148,750$. Another example is Cuban-born Tomas Sanchez's “Luz de una Tarde de Tormenta,” sold in 1995 for $\$ 29,900$ and later in 2002 for $\$ 65,725$. A dummy variable sale was created which equal to one if the painting has previously been put for auction at Sotheby's, 0 otherwise. We found that about $13 \%$ of the paintings had been auctioned before. ${ }^{24}$

There are a number of variables that refer strictly to the artist, not to the artwork, that we believe may have an impact on the price of a painting. Artists were classified according to their nationalities depending on where they lived and did most of their work. This information is also taken from the pre-auction catalogue. For instance, Leonora Carrington was born in England but moved to Mexico when she was 24. She was classified as a Mexican artist. For simplicity, some nationalities were later aggregated into Central America (Nicaragua, Costa Rica, Panama, Guatemala and El Salvador) and Caribbean (Cuba, Haiti, Puerto Rico and Dominican Republic). Accordingly, 62\% of the painters in our sample are of Mexican or Caribbean origin.

Variables capturing the year the painter was born (and died, if applicable) were also constructed. The minimum year of birth is 1649 and the maximum is 1972. A variable dead was also created: a dummy variable that equals one if the painter is dead and 0 if he is alive at the time of the auction. We find that $52 \%$ of the painters were dead at the time of the auction and $48 \%$ alive.

We now turn to information on each painting. Most paintings have a date, either on its surface or on its back. When they do not have a date, art experts provide an estimate. For our purposes, if a work was painted circa 1960-1964, we assumed the mid-point (e.g., 1962) as being the date of execution. With this information, we calculated the artists' age at the date of

\footnotetext{
${ }^{24}$ Unfortunately, most of them we previously auctioned before 1995.
} 
execution. ${ }^{25}$ The average date of execution for our sample is 1957 and the average artist's age is 45 years old.

Among the physical characteristics of a painting which we consider are its dimensions and medium. Measurements for height and width are rounded to the nearest decimal. The mean surface of the works in our sample is 8,261 square centimetres. The four dummy variables created to quantify the medium are oil, watercolour, gouache, and other. The latter includes other media such as acrylic, pastel, graphite, crayon, ink, and charcoal. Oil paintings account for $60 \%$ of the works, gouaches for $9 \%$, watercolours for $6 \%$ and others for $5 \%$.

Next we face the difficult task of sorting the paintings according to genre or theme. There is an unavoidable degree of subjectivity in classifying paintings according to subject matter. All paintings are compositions in a general sense. Compositions, stricto sensu, are complex themes, associated with an intricate pattern of interaction among nature, human figure, objects-symbols, colours, and shapes. The four thematic categories we choose are stilllife, landscape, portrait and composition. Abstract paintings are categorized as compositions. As a rule, we considered the work a portrait when the individual (or group of individuals) portrayed occupies more than $50 \%$ of the area of the painting. We found that about $23 \%$ of the paintings are compositions, $27 \%$ are landscapes, $42 \%$ are portraits, and $7 \%$ are still-life.

The history of a work of art is another characteristic that we investigate in the expectation that it may have some positive influence on its market value. The pre-auction catalogue states the provenance of most paintings. They tend to originate either from a private collection or from a public institution (a gallery or museum). Some paintings are acquired directly from the artist. Others are bought from galleries. We created the dummy variables

\footnotetext{
${ }^{25}$ Galenson (2000) estimates the relationship between artists' ages at the time of execution and the value of their work for a group of successful twentieth-century American artists. He shows that those artists who were born in the 1920s and 1930s are much more likely to have done their most valuable work at an early age than their counterparts born between 1900 and 1920. He argues that this was driven by a shift in the demand for modern art.
} 
private and public: the former equals one if the catalogue states that the provenance is from a private collection (zero otherwise) and the latter equals one if the catalogue states that the provenance is from a public collection (zero otherwise). In our sample, approximately $85 \%$ of the paintings come from private and $31 \%$ from public collections. These are non excludable because paintings often had more than one owner.

When a painting is reproduced in an art book, it adds to its reputation, authenticity, and arguably to its price. The ultimate proof of authenticity of a painting is its inclusion in the catalogue raisonné of an artist. A catalogue raisonné is a comprehensive and scholarly listing of an artist's work, or work in a particular medium or from a specific phase, and generally includes the date, history, provenance, location, and other critical information about each individual piece. ${ }^{26}$ We create two dummy variables to capture this information: cat_raisonne and artbook. The variable cat_raisonne takes the value of one if the work is reported to have appeared in the artist's catalogue raisonné, zero otherwise. Still using the information provided in the pre-auction catalogue, for those paintings which have appeared in any other book, the variable artbook is coded 1, zero otherwise. In the same vein, we have also generated a dummy variable for whether the painting was selected as part of an important exhibition (exhibited). It is crucial to stress that in the cases of the two publication variables above as well as of exhibited, pre-auction catalogue information refers to extremely prominent and influential publications and exhibitions. At this level, most paintings have at some point been part of an art exhibition as well as been reproduced in some book, catalogue or publication. It is reasonable to expect that Sotheby's uses valuable catalogue space to report the fact that the piece has been reproduced in a book (or exhibited) only if these are perceived as an important work of reference (such as a History of Latin American Art) or as an

\footnotetext{
${ }^{26}$ Not all artists in our sample have achieved high enough reputation, high enough level of scholarly interest, or high enough demand in the arts market to justify having a catalogue raisonné.
} 
important exhibition. In our sample, $15 \%$ of the paintings appeared in an art book, $4 \%$ appeared in catalogue raisonnés, and 25\% have participated in important art exhibitions. We expect such references to have a positive effect on prices.

\section{Results}

The first question we investigate refers to the role of art experts in determining the probability that a painting is sold, or more specifically, in determining the probability that the actual ("hammer") price is above the seller's reserve price which is, as noted, unobservable. We investigate this issue using two different approaches. The first one is suggested by Ashenfelter et al. (2002) and is based on the predictive power of the range of pre-auction price estimates supplied by the auction house specialised department (Sotheby's Latin American Art Department in this case). The second approach is that developed by Ekelund et al. (1998) which, in addition to the range of price estimates, use a number of variations such the midpoint of the range, the gap between the latter and the actual price, and an estimate window.

Table 1 has the results for the role of art experts using the approach developed by Ashenfelter et al. (2002). We use the fixed-effects probit estimator to investigate whether art expert estimates have an effect on "no sales." Our baseline specification in column 1 has sale as a function of whether the painting was sold in auction before, whether it participated in art exhibitions, whether it is included in the catalogue raisonné of the artist, whether it is reproduced in an influential art book, whether it is signed, the year the painting was executed and the area of the painting. To these, we add fixed-effects for the individual auctions as well as the range of pre-auction price estimates which is our main variable of interest. The results show that predicting whether a painting sells is a rather difficult task. With the exception of the auction dummies, none of our variables is statistically significant and this includes the 
range of pre-auction price estimates. ${ }^{27}$

In column 2 of Table 1 we add medium of the painting (oil, watercolour, etc.) and the age of the artist when the painting was executed. Although there are some interesting results from these additional controls, the finding that pre-price estimates play little role in explaining sale rates remains. With respect to medium, watercolours have a higher probability of sale vis-à-vis other mediums and the same can be said with respect to younger artists. The specification in Column 3 tries to elaborate on this latter result by substituting whether the artist is dead for age. The results seem to confirm that paintings from younger artists and those alive at the time of the auction have a higher probability of sale. These results are of interest, for instance, in light of recent work by Galenson (2002) which finds different priceage profiles for artists from different art movements. The specification in column 4 tries to evaluate whether other characteristics of the painting would have an effect on the probability of sale. Somewhat surprisingly, still-life paintings seem more likely to sell while the results discussed above still hold. ${ }^{28}$ Finally column 5 adds another set of fixed-effects for different nationalities (these fixed-effects reflect inter alia economic and political developments in each artist's country of origin.) This does not change any of our previous results and we still find that the range of pre-auction price estimates plays little role in explaining the probability that a painting will sell in auction. ${ }^{29}$

Ekelund, Ressler and Watson (1998) use data from Latin American art auctions from 1977 to 1996 to investigate the existence of bias in pre-auction price estimates and whether any potential bias would be related to the "no sale” probability. Along previous findings, they report that although the bias exists, it is relatively small. Yet, they also note that their

\footnotetext{
${ }^{27}$ It is important to keep in mind that these results do not distinguish between the completion of a sale and the price at which a sale is transacted, a point to which we return below.

${ }^{28}$ The table does not contain the marginal effects. Using column 5 and evaluating at the mean, the fact that an artwork is a still-life paintings (watercolour) has a 15\% (12\%) higher probability of being sold.

${ }^{29}$ These results are also robust to the inclusion of the minimum price estimate.
} 
"estimate window" is negatively and significantly related to the likelihood of a "no sale." Their "estimate window" is computed as the ratio between the range of price estimates to their mid-point. They report one specification that relates whether a painting was sold to whether it is signed, the area of the painting (in centimetres square), its date, whether it was auctioned by Sotheby's or Christie’s and the "estimate window.” They find that all of these variables, with the exception of the area, have expected and statistically significant effects on the probability of "no sale," including the fact that their "estimate window" is negatively and significantly related to the likelihood of a "no sale" at auction. The intuition being that a more precise estimate would translate in a higher sale probability. This is a novel and interesting result.

Using Sotheby’s data for the period 1995 to 2002, we investigate whether Ekelund et al. results hold. Table 2 reports our estimates for their specification. The only difference between theirs and ours is that we do not have a variable for auction house as all our data are from Sotheby's. The results shown in Table 2 are fundamentally different from those reported in Ekelund et al. in that their "estimated window" has little explanatory power in determining whether or not a painting sell at auction. Moreover, the fact that the coefficients on signed and date are also never statistically significant suggests that the difference between these results is driven by more than simply auction house pricing policy. It is our conjecture that learning plays a role in this divergence. The estimates in Ekelund et al. give more weight to the very early years of these auctions (recall Latin American Art auctions started in 1977 at Sotheby's, and in 1981 at Christie’s.) It is conceivable that, after the first two or three years of existence, the Latin American Art Department learned how to produce better price estimates. ${ }^{30}$ Our results in Table 2 show that the "estimate window" plays very little role in explaining the probability of sale, and this result is robust across a variety of specifications.

\footnotetext{
30 A non-conflicting explanation is that their time frame is 1977 to 1996 and it was only in the early 1980s that a New York State law requiring disclosure of no sales was passed. An interesting question for future research is whether this law had an impact on pre-auction price estimates.
} 
We now turn to the second issue we investigate in this paper, namely, to estimate and compare average actual prices, art expert's price estimates and hedonic prices. These are used in this paper to calculate returns to investing in Latin American art. Figure 1 presents the three price indexes we computed. The first is simply the unweighted average price per auction. The second index, labelled, “index of art expert's price estimates” is the unweighted mean of the minimum and maximum price estimates produced by Sotheby's Latin American Art Department and published in the pre-auction catalogue. The behaviour of the two indices over auctions (over time) is similar, especially after 1997. They both show that Latin American art has appreciated in value between 1995 and 2002. The third index shown in Figure 1 is our hedonic price index for Latin art between 1995 and 2002. There are some noteworthy differences. First, and in line with other results in the literature (e.g., Buelens and Ginsburgh, 1993), the hedonic index does not exhibit the same variability of the other two indices. Further, returns calculated using this index are higher because it identifies only one trough in 1997 (as opposed to two, 1997 and 2001, for the two other indices). Also note that the hedonic index underestimates auction prices at various points, which is consistent with the common perception that "better" paintings tend to come to the market during "booms."

How is our hedonic price index computed? We follow the literature and estimate equation (1) above by OLS but including artist and nationality fixed-effects (that is, we add dummy variables for individual artists and individual nationalities). We add nationality fixedeffects in order to take into account economic and political developments in each artist's country of origin. We add artist fixed-effects to capture various unobservable characteristics, including artist’s reputation (Rengers and Velthuis, 2002).

Table 3 shows the results from our hedonic price regressions. Column 1 provides corroboratory evidence for one result that economists have been generating for a while in this field, to the disbelief of those in the arts trade, namely that size matters. In other words, the 
physical dimensions of a painting (log of its area) are on average a very important determinant of a painting's "hammer price.” Also reassuring is the result that oil paintings command higher prices than paintings in other media. One somewhat unexpected result is that whether a painting is signed (or signed and dated, not shown) affects negatively its price. One would think that the presence of a signature reduces uncertainty about the authenticity of the painting. Notice that this result remains despite the inclusion of other variables which signal reduced uncertainty (such as whether the painting is included in the catalogue raisonné of the artist). Yet, this coefficient does loose statistical significance if the nationality fixed-effects are excluded. ${ }^{31}$ Column 2 in Table 3 shows this specification enlarged by genre (or theme). We learn that for Latin American art, still-life as the genre of a painting is positively associated with a higher price in auctions. Column 4 shows our preferred specification (the one used to construct the hedonic price index). One striking result is that the reputation of the author and the provenance of the work turns out to be crucially important determinants of the "hammer price" of a painting. We also find that the price of a painting tends to increase if it was included in an art exhibition, included in the catalogue raisonné, reproduced in an influential art book or if it originates from a public institution (a gallery or museum). ${ }^{32}$ These results in a sense justify our data collection effort as this important array of variables is often unavailable from the aforementioned commonly used electronic databases. The exclusion of such variables and the fact that they are often statistically significant implies that previous analyses are not immune to omitted variables bias.

Hedonic regression models are also useful to calculate average returns. This is

\footnotetext{
${ }^{31}$ There are a number of factors that may reduce the effect of the painter's signature. One is that more than half of the painters were alive at the time of auction (so authorship attribution can be accomplished at relatively little cost.) Another is that most of paintings in the sample are signed (more than $90 \%$ of them) so there is very little variance to be explained. Last, but not least, only Latin American major paintings and major painters are auctioned at Sotheby's, so authenticity is often not a major issue in this market segment.

${ }^{32}$ Also noteworthy is that whether the painting was sold before in auction or comes from a private collection seem less important with respect to price.
} 
normally done by substituting a trend variable for the year/auction dummies. Using the results in column 4 of Table 4, we estimate that the average annual return on Latin American art between 1995 and 2002 was 5.23\%. This rate is of course below (mind this is the "dot com" period) the returns generated by other assets in the same period (in New York). It is important to note that these results are not out of line with the seminal insights from Baumol (1986) that suggest that returns from art works are lower than returns from other assets, such as common stocks, because art works are simultaneously consumption and investment goods. Again, these results should be interpreted with caution because of the rather short time period covered by our data.

The calculation of returns enables us to investigate the existence of what is known as the "masterpiece effect." This refers to the very common perception among art dealers that masterpieces perform better than the rest of the market. In other words, the conventional wisdom is that the returns to the best pieces of art tend to be significantly above normal. Like the correlation between price and the area of the paintings, this is another issue in which economists' disagree with those in the arts trade and have repeatedly put forward empirical findings that suggest that the masterpiece effect does not hold. ${ }^{33}$ How one defines a "masterpiece" is, of course, crucial. The way such tests are often carried out in this literature is to define the $20 \%$ most expensive lots in an auction as masterpieces and then compare the returns for the top $20 \%$ with the returns to the bottom $80 \%$. Based on the specification in column 4, we estimate that the average annual return to a “masterpiece” between 1995 and 2002 was $-1.92 \%$, while the same figure for the "non-masterpieces” was 5.63\%. In a nutshell, our results do not support the notion that the "masterpiece effect" is one of the main features of the arts market. ${ }^{34}$

\footnotetext{
33 See, among others, Pesando (1993), Ashenfelter et al. (2002), and Mei and Moses (2002).

${ }^{34}$ These results are qualitatively the same for the other specifications in Table 4.
} 
However, our unique data set contains variables that can provide an alternative identification of a masterpiece and, consequently, an alternative way to test the strength of the masterpiece effect. We believe there are three variables that may be useful in this regard. One is whether or not the painting has previously participated in a prestigious art exhibition. Another reflects whether the painting is included in an influential art book. And the third reflects whether or not the painting is included in the catalogue raisonné. We re-estimate the average annual returns for these categories, in the same way as above, the only difference being that we use the specification without these reputation variables (that is, the specification in column 3, Table 3). We estimate that the average annual return to an exhibited painting between 1995 and 2002 was 5.29\%, while the same figure for "non-exhibited” paintings was $5.6 \%$; that the average annual return to a painting that appeared in an art book was $2.21 \%$, while the same figure for the "non-art book" paintings was $6.06 \%$; and that the average annual return over the same period to a painting that appeared in a catalogue raisonné was $8.96 \%$, while the same figure for the "non- catalogue raisonné" painting was $5.87 \%$. In short, for two of our three potential masterpiece identifiers, we find that the returns for the nonmasterpieces were substantially larger. Yet, there is limited support for the masterpiece effect if we use as identifier whether or not the paintings appeared in the catalogue raisonné. These results should be interpreted with caution for at least two reasons: one is that there are too few years over which these differences in returns are being calculated and the second is that the number of paintings that appeared in the catalogue raisonné is small (less than $4 \%$ of our sample.)

Finally, we turn to the question of whether or not Latin American art auctions are also subject to the "declining price anomaly" or the so-called "afternoon effect." This was first identified by Ashenfelter (1989) and is a repudiation of the law of one price. It refers to the observation that as an auction proceeds the prices of the lots decline, even for identical goods 
(in Ashenfelter, 1989, identical wines). Beggs and Graddy (1997) established the existence of the "declining price anomaly" for heterogeneous goods using data for Contemporary and Impressionist art auctions. This has generated great interest and a number of papers now report somewhat conflicting results in this respect, although the majority still seems to find evidence that supports this anomaly (see Ashenfelter and Graddy, 2003, for a review of this evidence.) In light of this controversy, it is of obvious interest to investigate whether or not Latin American art auctions are also subject to the “declining price anomaly.” Table 4 contain our set of estimates trying to throw light on this issue. In columns 1 and 3 , we investigate the effect of how late the lot appears in an auction (the lot order) on the hammer price, while on columns 2 and 4 we investigate this effect on the average pre-auction price estimate. Columns 1 and 2 look at this effect conditional only on the individual auctions, while columns 3 and 4 study whether this effect also holds conditional on artist dummies and various characteristics of the painting. ${ }^{35}$ The coefficient on lot order is negative and statistically significant throughout providing somewhat strong evidence for the "declining price anomaly” in our Latin American art auctions data.

\section{Concluding remarks}

This paper studies several empirical puzzles from the recent auctions literature. It does that on the basis of a unique data set of Latin American paintings auctioned by Sotheby's between 1995 and 2002. The data set is unique: it differs from previous studies in that we collect by hand all the information available in the pre-auction catalogues. This comprehensive approach enables us to consider the effects of a number of potentially important variables that have received relatively little attention previously. As noted, we believe that this is not because the

\footnotetext{
${ }^{35}$ For the sake of comparability, we use the same specification as Beggs and Graddy (1997). Yet, as it can be seen, including our variables on reputation and provenance does not change this conclusion.
} 
data were unavailable, but because the private firms that specialize in the provision of electronic data on art auctions may have judged that information on artist's reputation and the provenance of artwork would be common knowledge to art auction buyers (or maybe because the quantification of this information is expensive and time-consuming). This should imply neither that this information in unobservable to the analyst nor that it is irrelevant to art buyers. Indeed, the results from our econometric analysis vindicate this effort as some variables (omitted in the vast majority of previous studies) turn out to play a more important role than some of the variables one commonly finds in similar studies. Specifically, our results show that artist's reputation and artwork's provenance seem to be more important determinants of the sale price of a painting than factors such as medium and size. We also find that, contrary to previous research, experts' opinion has rather limited power in predicting the sale of artwork. Notice, however, that we have here considered only one set of art experts, those employed by the Sotheby's Latin American Art Department. Maybe a different set of experts would generate better predictions. This is important because many suspect that in-house experts can be influenced by sellers when setting the lower price estimates (Mei and Moses, 2005). In line with previous research, we find that the notion that “masterpieces” command above normal returns does not seem to hold for our sample of paintings. Finally, one of the central puzzles in the auction literature identified using art auctions data is the "declining price anomaly." This refers to identical lots commanding different prices depending on where along the auction they are placed, with lots placed earlier in the auction receiving higher bids and consequently selling for higher prices. Our study provides corroboratory evidence for this anomaly. 


\section{References}

Ashenfelter, Orley (1989) “How auctions work for wine and art,"Journal of Economic Perspectives 3, 23-36.

Ashenfelter, Orley and Kathryn Graddy (2003) “Auctions and the price of art,” Journal of Economic Literature, September

Ashenfelter, Orley, Kathryn Graddy and Margareth Stevens (2002) "An empirical study of sales rates and prices in Impressionist and Contemporary Art auctions," Oxford University, mimeo.

Baumol, William J. (1986) “Unnatural value or art investment as a floating crap game,” American Economic Review Volume 76(2), 10-15.

Beckert, J. and J. Rössel (2004), “Art and Prices: Reputation as a Mechanism for Reducing Uncertainty in the Art Market,” Kölner Zeitschrift für Soziologie und Sozialpsychologie, 56:32-50.

Beggs, A and K Graddy, "Declining values and the afternoon effect: Evidence from art auctions,” Rand Journal of Economics, 1997, Vol. 23, 544-565.

Buelens, Nathalie, and Victor Ginsburgh, "Revisiting Baumol's Art investment as floating crap game,” European Economic Review 37 (1993), 1351-1371.

Burton Benjamin and Joyce Jacobsen (1999), "Measuring returns on investments in collectibles,”_Journal of Economic Perspectives 13 (4), 193-212.

Chanel, Olivier (1995) “Is art market behaviour predictable?” European Economic Review Volume 39, 519-527.

Chanel, Olivier, Louis-Andre Gérard-Varet and Victor Ginsburgh (1994), Prices and returns on paintings: an exercise on how to price the priceless, The Geneva Papers on Risk and Insurance Theory 19, 7-21.

Chanel, Olivier, Louis-Andre Gérard-Varet and Victor Ginsburgh (1996), The relevance of hedonic price indexes: The case of paintings, Journal of Cultural Economics 20, 1-24.

Chow, Gregory C., 1967: “Technological Change and the Demand for Computers,” American Economic Review, Vol. 57, no. 5, 1117-1130.

Court, Andrew. (1939), "Hedonic Price Indexes with Automotive Examples", in The Dynamics of Automobile Demand, pp.99-117, General Motors Corporation.

de la Barre, Madeleine, Docclo, Sophie and Victor Ginsburgh (1994), "Returns of Impressionist, Modern and Contemporary European paintings, 1962-1991," Annales d'Economie and Statistique, 35: 143-181.

Edwards, Sebastian (2004), "The economics of Latin American art: Creativity patterns and rates of return,” Economía, Spring 1-35. 
Ekelund, Robert B., Rand W. Ressler and John Keith Watson (1998), "Estimates, bias and 'No Sales' in Latin American art auctions, 1977-1996," Journal of Cultural Economics Volume 22, 33-42.

Ekelund, Robert B., Rand W. Ressler and John Keith Watson (2000), "The 'Death-Effect' in Art Prices: A Demand-Side Exploration,” Journal of Cultural Economics Volume 24, 283-300.

Frey, Bruno S. and Pommerehne, Werner W. (1989), Muses and Markets: Explorations in the economics of the arts. Basil Blackwell.

Frey, Bruno S. and Eichenberger, R. (1995), "On the rate of return in the art market: Survey and evaluation,” European Economic Review Volume 39, 528-537.

Galenson, David W. (2002), “The careers of Modern artists,” Journal of Cultural Economics Volume 24, 87-112.

Gerard-Varet, L. (1995). "On Pricing the priceless: Comments on the economics of the visual art market.” European Economic Review, 39, 509-518.

Ginsburgh, V., J. Mei and M. Moses (2006), “The Computation of Price Indices,” in Ginsburgh, V. and D. Throsby (eds.), Handbook on Economics of Art and Culture, Elsevier, Amsterdam.

Ginsburgh, Victor and Jan van Ours (2003), "How to Organize Sequential Auctions: Results of a Natural Experiment by Christie’s,” Tilburg, CenTER Discussion Paper 2003-25.

Goetzmann, William N (1993), “Accounting for Taste: Art and the Financial Markets Over Three Centuries” American Economic Review Volume 83(5), 1370-1376.

Hulten, C. (2003), “Price Hedonics: A Critical Review,” Federal Reserve Bank of New York, FRBNY Economic Policy Review, September 2003: 1-15.

Klemperer, Paul (2004), Auctions: Theory and Practice, Princeton University Press.

Mei, J. and M. Moses (2002). "Art as an Investment and the Underperformance of Masterpieces,” American Economic Review, 92(5), pages 1656-1668.

Mei, J. and M. Moses (2005), "Vested Interests and Biased Price Estimates: Evidence from An Auction Market,” Journal of Finance, 60, 2409-2436.

Nerlove, M. (1995), "Hedonic Price Functions and The Measurement of Preferences: The Case of Swedish Wine Consumers” European Economic Review Volume 39, 1697-1716.

Pesando, J. (1993), “Art as an Investment: The Market for Modern Prints,” American Economic Review 83, 1075-1089.

Rengers, M. and Velthuis, O. (2002), "Determinants of Prices for Contemporary Art in Dutch Galleries, 1992-1998” Journal of Cultural Economics Volume 26, 1-28. 
Rosen, S (1974), "Hedonic Prices and Implicit Markets: Product Differentiation in Pure Competition,” Journal of Political Economy 82, 34-55.

Rouget, Bernard and Sagot-Duvauroux, Dominique (1996), Economie des arts plastiques: Une analyse de la médiation culturelle, Paris : L'Harmattan.

Sagot-Duvauroux, Dominique (2003), “Art Prices,” in Ruth Towse (editor) A Handbook of Cultural Economics, Edward Elgar, 57-63.

Schönfeld, Susanne and Andreas Reinstaller (2007), "The Effects of Gallery and Artist Reputation on Prices in the Primary Market for Art: A Note," Journal of Cultural Economics 31 (No. 2):143-153.

Throsby, D. (1994), “The Production and Consumption of the Arts: A View of Cultural Economics” Journal of Economic Literature 32 (1994), 1-29.

Tomat, Gian M. (2002), “Durable Goods, Price Indexes and Quality Change: An Application to automobile prices in Italy, 1988-1998” European Central Bank WP 118.

Triplett, J. (2004), "Handbook on Hedonic Indexes And Quality Adjustments In Price Indexes: Special Application To Information Technology Products,” OECD STI Working Paper 2004/9.

Valsan, C. (2002), “Canadian versus American Art: What Pays Off and Why,” Journal of Cultural Economics Volume 26, 203-216.

Waugh, F.V. (1928). “Quality Factors Influencing Vegetable Prices.” Journal of Farm Economics. Volume 10,185-196. 
Figure 1. Price Indices forLatin American Art:

Comparing actual, expert's estimates and hedonic prices (1995=100)

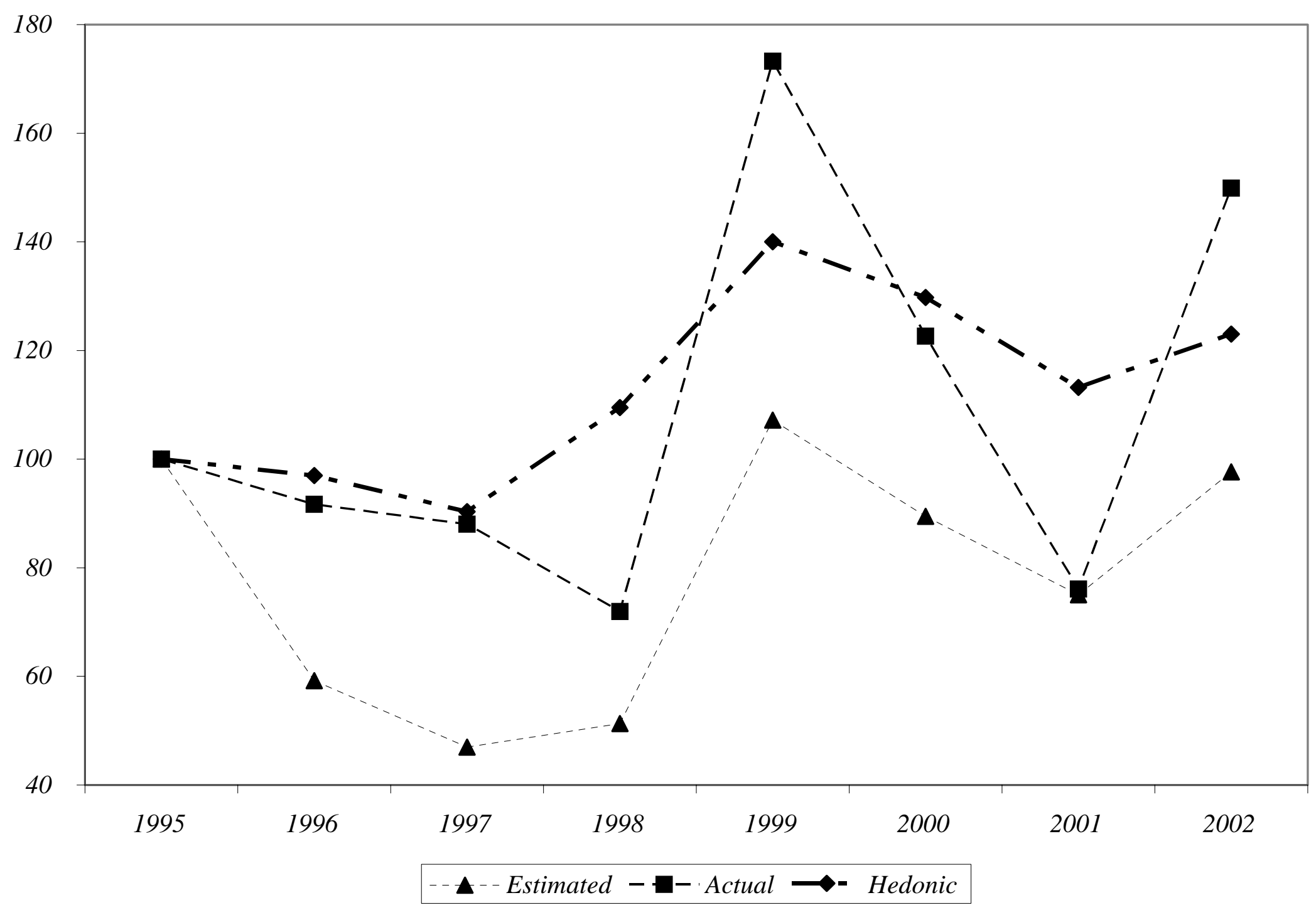




\begin{tabular}{|c|c|c|c|c|c|}
\hline \multicolumn{6}{|c|}{$\begin{array}{c}\text { Table 1 } \\
\text { The Determinants of No-sales } \\
\text { (Ashenfelter, Graddy and Stevens' Art Expert Price Estimate Measure) } \\
\text { Probit estimates (dependent variable is whether painting was sold in auction) }\end{array}$} \\
\hline & 1 & 2 & 3 & 4 & 5 \\
\hline Sale & $\begin{array}{l}.098 \\
(.102)\end{array}$ & $\begin{array}{l}.103 \\
(.102)\end{array}$ & $\begin{array}{l}.098 \\
(.102)\end{array}$ & $\begin{array}{l}.129 \\
(.104)\end{array}$ & $\begin{array}{l}.131 \\
(.105)\end{array}$ \\
\hline Art Expert's Estimate & $\begin{array}{l}-.001 \\
(.001)\end{array}$ & $\begin{array}{l}-.001 \\
(.001)\end{array}$ & $\begin{array}{l}-.001 \\
(.001)\end{array}$ & $\begin{array}{l}-.001 \\
(.001)\end{array}$ & $\begin{array}{l}-.001 \\
(.001)\end{array}$ \\
\hline Exhibited & $\begin{array}{l}.062 \\
(.083)\end{array}$ & $\begin{array}{l}.065 \\
(.083)\end{array}$ & $\begin{array}{l}.067 \\
(.083)\end{array}$ & $\begin{array}{l}.086 \\
(.085)\end{array}$ & $\begin{array}{l}.082 \\
(.086)\end{array}$ \\
\hline Art books & $\begin{array}{l}.126 \\
(.107)\end{array}$ & $\begin{array}{l}.118 \\
(.108)\end{array}$ & $\begin{array}{l}.126 \\
(.108)\end{array}$ & $\begin{array}{l}.124 \\
(.110)\end{array}$ & $\begin{array}{l}.133 \\
(.111)\end{array}$ \\
\hline Catalogue raisonné & $\begin{array}{l}.118 \\
(.204)\end{array}$ & $\begin{array}{l}.134 \\
(.204)\end{array}$ & $\begin{array}{l}.135 \\
(.204)\end{array}$ & $\begin{array}{l}.127 \\
(.206)\end{array}$ & $\begin{array}{l}.151 \\
(.207)\end{array}$ \\
\hline Signed & $\begin{array}{l}-.030 \\
(.118)\end{array}$ & $\begin{array}{l}-.026 \\
(.119)\end{array}$ & $\begin{array}{l}-.013 \\
(.120)\end{array}$ & $\begin{array}{l}-.041 \\
(.122)\end{array}$ & $\begin{array}{l}-.033 \\
(.124)\end{array}$ \\
\hline Area & $\begin{array}{l}.001 \\
(.001)\end{array}$ & $\begin{array}{l}.0016^{*} \\
(.001)\end{array}$ & $\begin{array}{l}.001 \\
(.001)\end{array}$ & $\begin{array}{l}.001 \\
(.001)\end{array}$ & $\begin{array}{l}.001 \\
(.001)\end{array}$ \\
\hline Executed & $\begin{array}{l}-.001 \\
(.001)\end{array}$ & $\begin{array}{l}-.001 \\
(.001)\end{array}$ & $\begin{array}{l}-.002 \\
(.001)\end{array}$ & $\begin{array}{l}-.002 \\
(.001)\end{array}$ & $\begin{array}{l}-.002 \\
(.002)\end{array}$ \\
\hline Oil & & $\begin{array}{l}.017 \\
(.079)\end{array}$ & $\begin{array}{l}.013 \\
(.079)\end{array}$ & $\begin{array}{l}-.009 \\
(.080)\end{array}$ & $\begin{array}{l}-.032 \\
(.083)\end{array}$ \\
\hline Age & & $\begin{array}{l}-.004 \\
(.002)\end{array}$ & $\begin{array}{l}-.002 \\
(.003)\end{array}$ & $\begin{array}{l}-.002 \\
(.003)\end{array}$ & $\begin{array}{l}-.002 \\
(.003)\end{array}$ \\
\hline Gouache & & $\begin{array}{l}.039 \\
(.127)\end{array}$ & $\begin{array}{l}.048 \\
(.127)\end{array}$ & $\begin{array}{l}.015 \\
(.128)\end{array}$ & $\begin{array}{l}.060 \\
(.131)\end{array}$ \\
\hline Watercolour & & $\begin{array}{l}.348 * * \\
(.157)\end{array}$ & $\begin{array}{l}.349 * * \\
(.157)\end{array}$ & $\begin{array}{l}.334 * * \\
(.158)\end{array}$ & $\begin{array}{l}.370 * * \\
(.160)\end{array}$ \\
\hline Dead & & & $\begin{array}{l}-.145^{*} \\
(.087)\end{array}$ & $\begin{array}{l}-.151^{*} \\
(.088)\end{array}$ & $\begin{array}{l}-.189 * \\
(.097)\end{array}$ \\
\hline Still life & & & & $\begin{array}{c}.491 * * * \\
(.151)\end{array}$ & $\begin{array}{c}.493 * * * \\
(.155)\end{array}$ \\
\hline Portrait & & & & $\begin{array}{l}.115 \\
(.087)\end{array}$ & $\begin{array}{c}.114 \\
(.094)\end{array}$ \\
\hline Landscape & & & & $\begin{array}{c}.111 \\
(.094)\end{array}$ & $\begin{array}{c}.094 \\
(.100)\end{array}$ \\
\hline Year dummies & Yes & Yes & Yes & Yes & Yes \\
\hline Nationality dummies & & & & & Yes \\
\hline Pseudo $\mathrm{R}^{2}$ & 0.0246 & 0.0287 & 0.0300 & 0.0353 & 0.0528 \\
\hline $\begin{array}{l}\text { Number of } \\
\text { observations }\end{array}$ & 1639 & 1639 & 1639 & 1615 & 1612 \\
\hline $\begin{array}{l}\text { Note: Standard errors in } \\
\text { level, ** Statistically sig }\end{array}$ & $\begin{array}{l}\text { thesis, c } \\
\text { nt at } 5\end{array}$ & $\begin{array}{l}\text { for hete } \\
\text { evel, *S }\end{array}$ & $\begin{array}{l}\text { ticity. * } \\
\text { lly sign }\end{array}$ & $\begin{array}{l}\text { tically s } \\
10 \text { perce }\end{array}$ & at 1 percen \\
\hline
\end{tabular}




\section{Table 2}

The Determinants of No-sales

(Ekelund, Ressler and Watson's Art Expert Price Estimate Measure) Probit estimates (dependent variable is whether painting was sold in auction)

\begin{tabular}{|c|c|c|c|c|c|c|}
\hline & 1 & 2 & 3 & 4 & 5 & 6 \\
\hline ERW Art Expert's & .129 & .303 & .307 & .177 & .356 & .369 \\
\hline Estimate & $(.343)$ & $(.351)$ & $(.352)$ & $(.346)$ & $(.355)$ & .357 \\
\hline Signed & -.017 & -.030 & -.035 & -.002 & -.018 & -.022 \\
\hline & $(.117)$ & $(.117)$ & (.118) & $(.118)$ & $(.118)$ & .119 \\
\hline Area & $\begin{array}{l}.001 \\
(.001)\end{array}$ & $\begin{array}{l}.001 \\
(.001)\end{array}$ & $\begin{array}{l}.001 \\
(.001)\end{array}$ & $\begin{array}{l}.001 \\
(.001)\end{array}$ & $\begin{array}{l}.001 \\
(.001)\end{array}$ & $\begin{array}{l}.001 \\
(.001)\end{array}$ \\
\hline Executed & $\begin{array}{c}-.002 \\
(.001)\end{array}$ & $\begin{array}{l}-.002 \\
(.001)\end{array}$ & $\begin{array}{l}-.002 \\
(.001)\end{array}$ & $\begin{array}{l}-.001 \\
(.001)\end{array}$ & $\begin{array}{l}-.001 \\
(.001)\end{array}$ & $\begin{array}{l}-.001 \\
.001\end{array}$ \\
\hline Private & & & $\begin{array}{l}.104 \\
(.118)\end{array}$ & & & \\
\hline Exhibited & & & & $\begin{array}{c}.049 \\
(.081)\end{array}$ & $\begin{array}{c}.058 \\
(.082)\end{array}$ & $\begin{array}{l}.056 \\
.082\end{array}$ \\
\hline Art books & & & & $\begin{array}{l}.098 \\
(.103)\end{array}$ & $\begin{array}{l}.136 \\
(.105)\end{array}$ & $\begin{array}{l}.122 \\
.106\end{array}$ \\
\hline Catalogue raisonné & & & & $\begin{array}{l}.170 \\
(.199)\end{array}$ & $\begin{array}{l}.117 \\
(.201)\end{array}$ & $\begin{array}{l}.112 \\
.201\end{array}$ \\
\hline Public & & & $\begin{array}{l}.076 \\
(.092)\end{array}$ & & & \\
\hline Sale & & & & & & $\begin{array}{c}097 \\
(.102)\end{array}$ \\
\hline Year dummies & & Yes & Yes & & Yes & Yes \\
\hline Pseudo $\mathrm{R}^{2}$ & 0.0011 & 0.0223 & 0.0228 & 0.0029 & 0.0246 & 0.0250 \\
\hline $\begin{array}{l}\text { Number of } \\
\text { observations }\end{array}$ & 1639 & 1639 & 1639 & 1639 & 1639 & 1639 \\
\hline
\end{tabular}




\section{Table 3}

What determines the price of Latin American art? OLS estimates (dependent variable is log price)

\begin{tabular}{|c|c|c|c|c|}
\hline & 1 & 2 & 3 & 4 \\
\hline \multirow[t]{2}{*}{ Oil } & $.679 * * *$ & $.663 * * *$ & $.592 * * *$ & $.526 * * *$ \\
\hline & $(.076)$ & $(.076)$ & $(.078)$ & $(.074)$ \\
\hline \multirow{2}{*}{ Gouache } & .011 & .021 & -.071 & -.094 \\
\hline & (.109) & $(.110)$ & $(.112)$ & $(.105)$ \\
\hline \multirow{2}{*}{ Watercolour } & .052 & .036 & .046 & .029 \\
\hline & $(.124)$ & $(.125)$ & $(.127)$ & $(.120)$ \\
\hline \multirow{2}{*}{ Signed } & $-.270 * * *$ & $-.244 * * *$ & $-.199 * *$ & $-.173^{*}$ \\
\hline & $(.101)$ & $(.102)$ & $(.104)$ & $(.098)$ \\
\hline \multirow{2}{*}{ Log area } & $.537 * * *$ & $.536 * * *$ & $.563 * * *$ & $.474 * * *$ \\
\hline & $(.029)$ & $(.030)$ & $(.030)$ & $(.030)$ \\
\hline \multirow{2}{*}{ Still-life } & & $.395 * * *$ & $.365 * * *$ & \\
\hline & & $(.133)$ & $(.133)$ & \\
\hline \multirow{2}{*}{ Portrait } & & .040 & -.020 & $-.281 *$ \\
\hline & & $(.097)$ & $(.098)$ & $(.108)$ \\
\hline \multirow{2}{*}{ Landscape } & & .147 & .096 & $-.195 *$ \\
\hline & & (.106) & $(.107)$ & $(.118)$ \\
\hline \multirow{2}{*}{ Age } & & & $-.008 * * *$ & .021 \\
\hline & & & $(.003)$ & $(.021)$ \\
\hline \multirow{2}{*}{ Dead } & & & -.168 & -.040 \\
\hline & & & $(.235)$ & $(.224)$ \\
\hline Private & & & & .112 \\
\hline \multirow[b]{2}{*}{ Public } & & & & $\begin{array}{l}(.092) \\
180 * *\end{array}$ \\
\hline & & & & $\begin{array}{l}.180^{2} \\
(.076)\end{array}$ \\
\hline \multirow{2}{*}{ Exhibited } & & & & $.307 * * *$ \\
\hline & & & & $(.069)$ \\
\hline \multirow{2}{*}{ Art books } & & & & $.369 * * *$ \\
\hline & & & & $(.081)$ \\
\hline \multirow{2}{*}{ Catalogue raisonné } & & & & $.439 * * *$ \\
\hline & & & & $(.138)$ \\
\hline \multirow{2}{*}{ Sale } & & & & .071 \\
\hline & & & & $(.073)$ \\
\hline \multirow{2}{*}{ Executed } & & & & -.026 \\
\hline & & & & $(.021)$ \\
\hline \multirow{2}{*}{ Abstract } & & & & $-.326^{* *}$ \\
\hline & & & & $(.126)$ \\
\hline Year dummies & Yes & Yes & Yes & Yes \\
\hline Artist dummies & Yes & Yes & Yes & Yes \\
\hline Nationality dummies & Yes & Yes & Yes & Yes \\
\hline Adjusted $\mathrm{R}^{2}$ & 0.6196 & 0.6227 & 0.6311 & 0.6751 \\
\hline Number of observations & 1120 & 1103 & 1086 & 1083 \\
\hline $\begin{array}{l}\text { Note: Standard errors in pa } \\
\text { percent level, ** Statistical } \\
\text { level, }\end{array}$ & $\begin{array}{l}\text { is, correctec } \\
\text { ificant at } 5\end{array}$ & $\begin{array}{l}\text { teroscedasti } \\
\text { level, * Sta }\end{array}$ & $\begin{array}{l}\text { * Statistical } \\
\text { ly significa }\end{array}$ & $\begin{array}{l}\text { ificant at } 1 \\
\text { percent }\end{array}$ \\
\hline
\end{tabular}




\section{Table 4}

Is the declining price anomaly present in Latin American art auctions? OLS estimates (dependent variable is log price of log average estimate as indicated)

\begin{tabular}{|c|c|c|c|c|}
\hline & Log price & $\begin{array}{c}\text { Log Average } \\
\text { estimate }\end{array}$ & Log price & $\begin{array}{c}\text { Log Average } \\
\text { estimate }\end{array}$ \\
\hline Lot order & $\begin{array}{c}-.011^{* * *} \\
(.000)\end{array}$ & $\begin{array}{c}-.010 * * * \\
(.000)\end{array}$ & $\begin{array}{c}-.007 * * * \\
(.000)\end{array}$ & $\begin{array}{c}-.007 * * * \\
(.000)\end{array}$ \\
\hline Executed & & & $\begin{array}{c}.001 \\
(.002)\end{array}$ & $\begin{array}{l}-.001 \\
(.002)\end{array}$ \\
\hline Length & & & $\begin{array}{c}.007 * * * \\
(.001)\end{array}$ & $\begin{array}{c}.006^{* * * *} \\
(.001)\end{array}$ \\
\hline Width & & & $\begin{array}{c}.003^{* * * *} \\
(.001)\end{array}$ & $\begin{array}{c}.004^{* * * *} \\
(.001)\end{array}$ \\
\hline Signed & & & $\begin{array}{l}-.063 \\
(.093)\end{array}$ & $\begin{array}{l}-.069 \\
(.071)\end{array}$ \\
\hline Oil & & & $\begin{array}{c}.663 * * * \\
(.068)\end{array}$ & $\begin{array}{c}.637 * * * \\
(.051)\end{array}$ \\
\hline Gouache & & & $\begin{array}{l}-.015 \\
(.099)\end{array}$ & $\begin{array}{l}.062 \\
(.077)\end{array}$ \\
\hline Watercolour & & & $\begin{array}{l}-.049 \\
(.112)\end{array}$ & $\begin{array}{l}-.070 \\
(.090)\end{array}$ \\
\hline Year dummies & Yes & Yes & Yes & Yes \\
\hline Artist dummies & Yes & Yes & Yes & Yes \\
\hline Adjusted $\mathrm{R}^{2}$ & 0.3821 & 0.3910 & 0.6989 & 0.6761 \\
\hline $\begin{array}{l}\text { Number of } \\
\text { observations }\end{array}$ & 1120 & 1661 & 1103 & 1638 \\
\hline
\end{tabular}




\section{APPENDIX}

\section{Basic statistics for pooled data}

\begin{tabular}{|c|c|c|c|c|c|c|}
\hline Variable & Definition & Obs. & Mean & Std. Dev. & Min & $\operatorname{Max}$ \\
\hline Price & Price paid for auctioned painting, in US Dollars & 1663 & 42743 & 134134 & 0 & 2642500 \\
\hline Sold & $\begin{array}{l}\text { Dummy variable for sale: coded } 1 \text { if painting was sold in } \\
\text { auction, } 0 \text { otherwise }\end{array}$ & 1663 & .674 & .469 & 0 & 1 \\
\hline Min_est_price & Pre-auction catalogue’s lower range price estimate & 1662 & 47507 & 105533 & 800 & 1500000 \\
\hline Max_est_price & Pre-auction catalogue’s upper range price estimate & 1662 & 66659 & 219175 & 1000 & 7000000 \\
\hline $\begin{array}{l}\text { ERW Art Expert's } \\
\text { Estimate }\end{array}$ & $\begin{array}{l}\text { Ekelund et al. "estimate window”: ratio between range of pre- } \\
\text { auction price estimates to their mid-point }\end{array}$ & 1662 & .299 & .096 & -.769 & 1.733 \\
\hline Sale & $\begin{array}{l}\text { Dummy variable for auction history: coded } 1 \text { if painting was sold } \\
\text { in auction previously, } 0 \text { otherwise }\end{array}$ & 1663 & .127 & .333 & 0 & 1 \\
\hline Private & $\begin{array}{l}\text { Dummy variable for provenance: coded } 1 \text { if painting originates } \\
\text { from private collection, } 0 \text { otherwise }\end{array}$ & 1663 & .852 & .355 & 0 & 1 \\
\hline Public & $\begin{array}{l}\text { Dummy variable for provenance: coded } 1 \text { if painting originates } \\
\text { from public collection (gallery or museum), } 0 \text { otherwise }\end{array}$ & 1663 & .311 & .463 & 0 & 1 \\
\hline Exhibited & $\begin{array}{l}\text { Dummy variable for exhibition: coded } 1 \text { if painting was part of } \\
\text { prestigious art exhibition, } 0 \text { otherwise }\end{array}$ & 1663 & .243 & .429 & 0 & 1 \\
\hline Art books & $\begin{array}{l}\text { Dummy variable for literature: coded } 1 \text { if painting was included } \\
\text { in prestigious art book, } 0 \text { otherwise }\end{array}$ & 1663 & .152 & .359 & 0 & 1 \\
\hline Catalogue raisonné & $\begin{array}{l}\text { Dummy variable for literature: coded } 1 \text { if painting was included } \\
\text { in the artist catalogue raisonne, } 0 \text { otherwise }\end{array}$ & 1663 & .036 & .187 & 0 & 1 \\
\hline Born & Painter's year of birth & 1663 & 1912 & 32 & 1649 & 1972 \\
\hline Died & Painter's year of death (if applicable) & 865 & 1964 & 32 & 1714 & 2001 \\
\hline Dead & $\begin{array}{l}\text { Dummy variable for death: coded } 1 \text { if painter was dead at time of } \\
\text { auction }\end{array}$ & 1663 & .521 & .500 & 0 & 1 \\
\hline
\end{tabular}




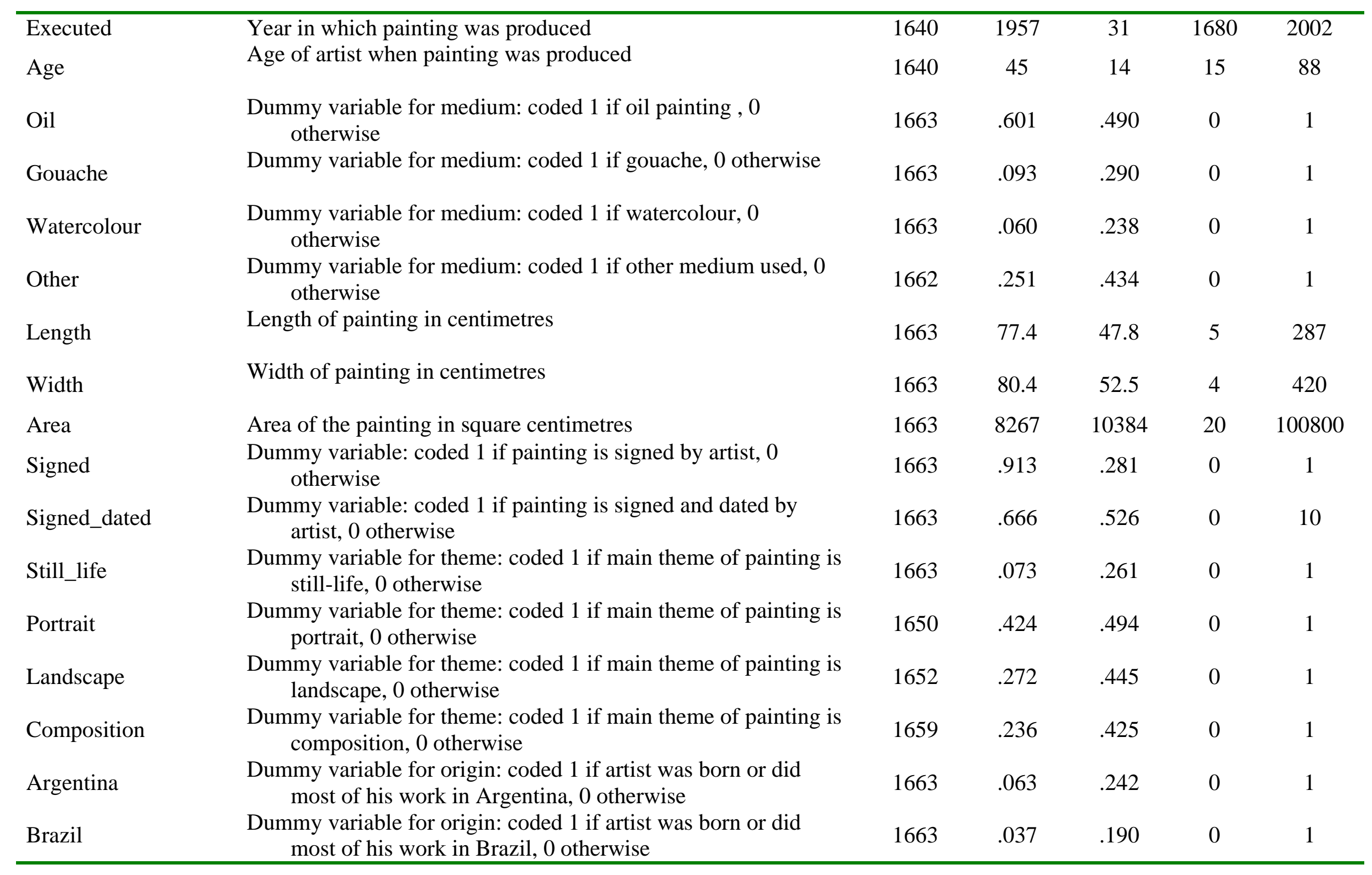




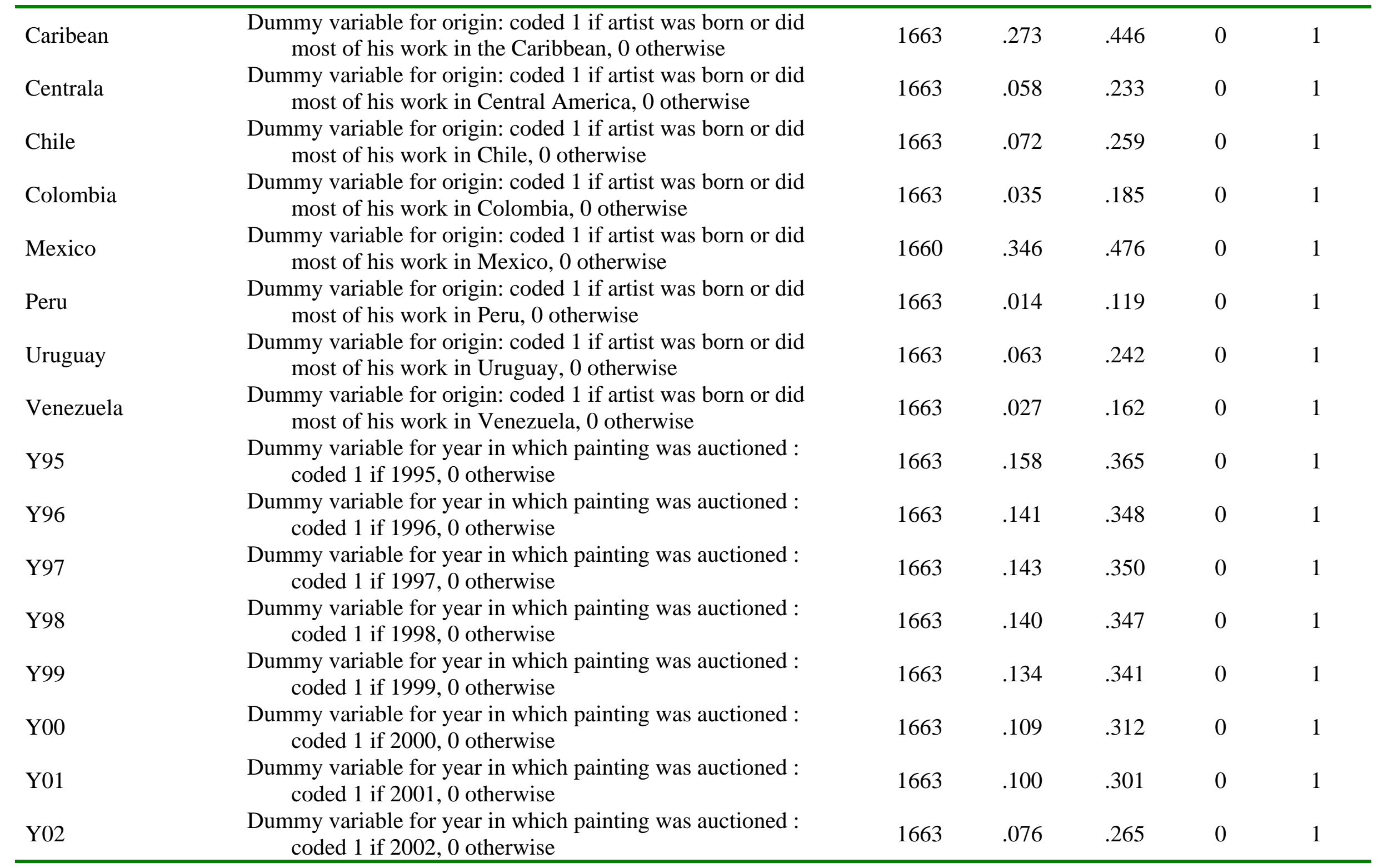

